\title{
Combined replacement of fish meal and oil in practical diets for fast growing juveniles of gilthead sea bream (Sparus aurata L.): Networking of systemic and local components of GH/IGF axis
}

\author{
Laura Benedito-Palos ${ }^{a}$, Alfonso Saera-Vila ${ }^{a}$, Josep-Alvar Calduch-Giner ${ }^{a}$, Sadasivam \\ Kaushik ${ }^{b}$ and Jaume Pérez-Sánchez ${ }^{a, ~ *}$
}

\begin{abstract}
a Instituto de Acuicultura de Torre de la Sal (CSIC), Department of Biology, Culture and Pathology of Marine Species, 12595 Ribera de Cabanes, Castellón, Spain

b UMR Nutrition, Aquaculture and Genomics, INRA, Unité-Mixte INRA-IFREMER-Univ. Bordeaux I, 64310 SaintPée-sur-Nivelle, France
\end{abstract}

*: Corresponding author : Jaume Pérez-Sánchez, email address : jperez@iats.csic.es

\begin{abstract}
:
Growth performance and growth regulatory pathways were examined in juvenile gilthead sea bream fed diets containing largely plant-based ingredients. Four isonitrogenous and isolipidic extruded diets with a low level (20\%) of fish meal inclusion were formulated with graded levels of a vegetable oil mixture (17:58:25 of rapeseed: linseed: palm oils) replacing fish oil at 33, 66 and 100\% (33VO, 66VO and VO diets). All diets were supplemented with lysine (0.55\%) and contained soy lecithin (1\%). Daily growth coefficients and feed efficiency over the course of an 11-week trial were almost identical in fish fed the FO, 33VO and 66VO diets. The VO diet reduced feed intake and growth without significant effects in proximate whole body composition, nitrogen or energy retentions. The highest concentration of plasma levels of insulin-like growth factor-I (IGF-I) was found in fish fed the 33VO diet. The lowest concentration was attained in fish fed the VO diet, whereas intermediate values were found in fish fed FO and 66VO diets. An opposite trend was found for circulating levels of growth hormone (GH), probably as a result of a reduced negative feedback inhibition from circulating IGF-I. Hepatic expression of IGF-I and GH receptor type I (GHR-I) was regulated in concert and mRNA levels paralleled plasma levels of IGF-I. Hepatic IGF-II and GHR-II were expressed in a more constitutive manner and no changes at the mRNA level were detected. In the skeletal muscle, IGF-I and GHR-I mRNAs did not vary significantly among groups. By contrast, IGF-II mRNA was up-regulated in fish fed the control diet, whereas the highest amount of GHR-II mRNA was attained in fish fed the 66VO diet. All together, these results suggest different growth compensatory mechanisms mediated by IGFII and GHR-II at the local tissue level. These new insights prompted us to propose that practical diets low in marine ingredients can be used over the productive cycle of gilthead sea bream when essential fatty acids are supplied above the requirement levels.
\end{abstract}

Keywords: Sparidae; Fish oil; Vegetable oil; Plant proteins; Growth hormone; Growth hormone receptors; Insulin-like growth factors; Endocrine disrupters; Contaminants 


\section{Introduction} (

Currently, aquaculture is the major consumer of fish meal, a protein-dense feedstuff that approximates the ideal amino acid profile of most cultured livestock. However, fish meal is a limited resource whose availability has remained stable from the late 1980s at approximately 6 million metric tonnes per annum, which limits the continuous growth of aquaculture production (FAO, 2004). Furthermore, inherent variability in fish meal composition due to species, season, geographic origin and processing leads to variation in quality (Opstvedt et al., 2003; Bragadóttir et al., 2004), and most of the future changes in developing novel aquafeeds should be focused on alternative protein sources.

The n-3 long-chain highly unsaturated fatty acids (n-3 HUFA) are naturally abundant in the marine environment, and fish oil is the major source of eicosapentaenoic acid (EPA, 20:5n-3) and docosahexaenoic acid (DHA, 20:6n-3) for aquafeeds. Besides the scarcity of fish oil, which is of great concern for marine fish, these animals have a limited capacity to biosynthesize n-3 HUFA from the shorter chain linolenic acid (18:3n-3), and both EPA and DHA become critical dietary constituents to ensure successful survival, growth, and development of these fish (Sargent et al., 1999, 2002). At this standpoint, it must be noted that fish meal also contains certain amounts of oil rich in n-3 HUFA, and the fish oil added to energized diets can be totally replaced by vegetable oils when fish meal is included at a high level in diets for Atlantic salmon (Bell et al., 2003; Bransden et al., 2003; Torstensen et al., 2004), rainbow trout (Richard et al., 2006a), and the freshwater African catfish (Ng et al., 2004). Similar results have been achieved in a typically marine fish such as turbot (Regost et al., 2003). A high fish oil replacement is also feasible in the Murray cod using casein-based diets (Francis et al., 2006). Likewise, up to $60 \%$ of fish oil added to 
diets has been replaced successfully in juvenile European sea bass (Montero et al., 2005; Mourente et al., 2005) and gilthead sea bream (Izquierdo et al., 2005), but the diets used in these studies also contained 35 to $40 \%$ fish meal.

Marine derived feedstuffs are also possible vectors of contaminants, such as PCBs, dioxins and other harmful chemicals affecting the safety of farm-raised fish (Jacobs et al., 2002). It is clear that reduction in fish oil levels can lead to a decrease in the contaminant levels of feed and consequently on fish filets (Berntssen et al., 2005; Bethune et al., 2006). Thus, the general consensus is that alternative protein and oil sources are needed to supplement or replace fish meal and fish oil in aquafeeds, contributing to long-term sustainability of the aquaculture industry (Hardy, 2004). In the present study, our objective was hence to maximize the combined replacement of fish meal and fish oil in practical diets for fast growing juveniles of gilthead sea bream. In earlier studies, we had shown that a good proportion of fish meal can be replaced by a mixture of plant protein sources in gilthead sea bream diets (Gómez-Requeni et al., 2003, 2004; Sitjà-Bobadilla et al., 2005). Based on these results, we attempted here to replace fish oil by a blend of vegetable oils, which have been already shown to be very effective in other fish species (Torstensen et al., 2005; Mourente and Bell, 2006; Richard et al., 2006a,b). To address this issue, growth and nutrient retention were analyzed in a conventional manner. Circulating levels of growth hormone $(\mathrm{GH})$ and insulin-like growth factor-I (IGF-I) were used as markers of growth and nutrient status (see Pérez-Sánchez and Le Bail, 1999; Dyer et al., 2004). Also, transcripts of IGFs and GH receptors (GHR) were measured in liver and skeletal muscle by means of real-time PCR assays. 


\title{
2. Materials and methods
}

\author{
2.1. Diets
}

As shown in Table 1, three diets $(33 \mathrm{VO}, 66 \mathrm{VO}$ and $\mathrm{VO})$ with relatively low fish meal inclusion $(20 \%)$ levels were formulated with practical plant protein ingredients for the graded replacement $(33,66$ and 100\%) of the added fish oil by a blend of vegetable oils (rapeseed oil: linseed oil: palm oil). A fish oil-based diet (FO diet) equal in lipid content $\left(220 \mathrm{~g} \mathrm{~kg}^{-1}\right)$ was used as the reference diet. Diets were supplemented with lysine $(0.55 \%)$ and contained soy lecithin (1\%). EPA plus DHA content varied on a dry matter basis between 2.3\% (FO diet) and $0.3 \%$ (VO diet), and the DHA/EPA ratio (1.1-1.2) remained constant. All diets were manufactured using a twin-screw extruder (Clextral, BC 45) in the INRA experimental research station of Donzacq (Landes, France), dried under hot air, sealed and kept in air-tight bags until use.

Diet samples were hydrolysed $\left(6 \mathrm{~N} \mathrm{HCl}, 110{ }^{\circ} \mathrm{C}\right)$ and amino acid analysis was performed using high-performance liquid chromatography. Tryptophan was determined by the colorimetric method of Basha and Roberts (1977) after alkaline hydrolysis of each sample (see Table 2). Fatty acid methyl esters (FAME) were prepared from aliquots of total lipid by acidcatalysed transmethylation for $16 \mathrm{~h}$ at $50{ }^{\circ} \mathrm{C}$ (Christie, 1982) after the addition of nonadecaenoic fatty acid (19:0) as an internal standard. FAMEs were extracted and separated in a Fisons Instruments GC 8000 Series (Thermo Electron Co., Rodano, Italy) gas chromatograph, equipped with a fused silica $30 \mathrm{~m}$ x $0.25 \mathrm{~mm}$ open tubular column (Tracer TR-WAX, film thickness: $0.25 \mu \mathrm{m}$-Teknockroma, Spain) and a cold column injection system, using helium as carrier and 50 to $220{ }^{\circ} \mathrm{C}$ thermal gradient. Peaks were recorded with Chrom-Card for Windows 
120 software (Fisons CE Instruments, Milan, Italy) and identified by comparison with known 121 standards (see Table 3).

\subsection{Growth trial and fish sampling} into 12 fibreglass tanks (500-1 capacity) in groups of 60 fish each. Water (37.5\%o salinity)

flow was $20 \mathrm{l} / \mathrm{min}$, and oxygen content of outlet water remained higher than $85 \%$ saturation. Day length increased over the course of the trial (May-August) following natural

131 changes at our latitude $\left(40^{\circ} 5^{\prime} \mathrm{N} ; 0^{\circ} 10^{\prime} \mathrm{E}\right)$. Water temperature also varied naturally 132 increasing from 17 to $25^{\circ} \mathrm{C}$. The growth study was undertaken over 11 weeks (74 days) and each diet was

134 randomly allocated to triplicate groups of fish. Feed was offered by hand to apparent visual 135 satiety in two meals per day (0900 and $1400 \mathrm{~h})$, and feed consumption was recorded daily.

136 Every 3 weeks, fish were counted and group-weighed under moderate anaesthesia (3-

137 aminobenzoic acid ethyl ester, MS 222; $100 \mu \mathrm{g} / \mathrm{ml})$. Blood and tissue sampling was done at

138 the end of the growth trial from randomly selected fish killed by a blow to the head. Five $\mathrm{h}$

139 after the morning meal (12 animals per diet; 4 animals per tank), blood samples were taken

140 from caudal vessels with heparinised syringes. Following overnight fasting $(20 \mathrm{~h}$ after the

141 second daily meal), 12 additional fish per dietary treatment were taken for sampling of

142 blood, liver and white skeletal muscle. Plasma was drawn after centrifugation at $3000 \times \mathrm{g}$

143 for $20 \mathrm{~min}$ at $4{ }^{\circ} \mathrm{C}$, and stored at $-30{ }^{\circ} \mathrm{C}$ until further hormone analyses. Liver and white 
144 muscle were rapidly excised, frozen in liquid nitrogen and stored at $-80{ }^{\circ} \mathrm{C}$ for RNA 145 extraction.

\subsection{Chemical composition analyses}

151 Kjeldahl method, fat after dichloromethane extraction by the Soxhlet method and gross energy in an adiabatic bomb calorimeter (IKA). Specimens for whole body analyses (a pooled sample of 10 fish at the beginning and pools of 5 fish per tank at the end of trial) were ground, and small aliquots were dried to estimate moisture content. The remaining samples were freeze-dried and chemical analyses were performed as indicated for experimental diets.

157

\subsection{GH and IGF-I radioimmunoassay}

159

Plasma GH levels were assayed by a homologous gilthead sea bream

161 radioimmunoassay (RIA), using recombinant GH as tracer and standard (Martínez-

162 Barberá et al., 1995). Sensitivity and midrange of the assay were $0.1 \mathrm{ng} / \mathrm{ml}$ and 2.1 to 2.3

$163 \mathrm{ng} / \mathrm{ml}$, respectively.

164 After acid-ethanol precipitation, circulating levels of IGF-I were measured with a 165 generic fish IGF-I RIA (Vega-Rubín de Celis et al., 2004). The assay was based on the use 166 of recombinant red sea bream IGF-I (GroPep, Adelaide, Australia) as tracer and standard, 167 and anti-barramundi (Asian sea bass) IGF-I serum (GroPep, Adelaide, Australia) (1:8000) 
168 as first antibody. A goat anti-rabbit IgG (1:20) (Biogenesis, Poole, UK) was used as

169 precipitating antibody. The sensitivity and midrange of the assay were 0.05 and 0.7 to 0.8

$170 \mathrm{ng} / \mathrm{ml}$, respectively.

\subsection{RNA extraction and $R T$ procedure}

173

174

175

176

177

Total RNA extraction was performed with the ABI PRISM ${ }^{\mathrm{TM}} 6100$ Nucleic Acid PrepStation (Applied Biosystems, CA, USA). Briefly, liver and white skeletal muscle were homogenized at a ratio of $25 \mathrm{mg} / \mathrm{ml}$ with a guanidine-detergent lysis reagent. The reaction mixture was treated with protease K, and RNA purification was achieved by passing the tissue lysate $(0.5 \mathrm{ml})$ through a purification tray containing an application-specific membrane. Wash solutions containing DNase were applied, and total RNA was eluted into a 96-well PCR plate. The RNA yield was $40-50 \mu \mathrm{g}$ with absorbance measures $\left(\mathrm{A}_{260 / 280}\right)$ of 1.9 to 2.1 .

Reverse transcription (RT) with random decamers was performed with the HighCapacity cDNA Archive Kit (Applied Biosystems). For this purpose, 500 ng total RNA were reverse transcribed in a final volume of $100 \mu \mathrm{l}$. RT reactions were incubated $10 \mathrm{~min}$ at $25{ }^{\circ} \mathrm{C}$ and $2 \mathrm{~h}$ at $37{ }^{\circ} \mathrm{C}$. Control reactions were run without reverse transcriptase and were used as negative real-time PCR controls.

\subsection{Real-time PCR}

Real-time PCR was performed using an iCycler IQ Real-time Detection System (Bio-Rad, Hercules, CA, USA) as previously described (Calduch-Giner et al., 2003). 
192 Diluted RT reactions were used for PCR reactions in $25 \mu$ volume. Each PCR-well

193 contained SYBR Green Master Mix (Bio-Rad) with specific primers for target and 194 reference genes at a final concentration of $0.9 \mu \mathrm{M}$ (see Table 4).

195 The efficiency of PCR reactions for target and reference genes varied between 87 196 and 97\%. The dynamic range of standard curves (serial dilutions of RT-PCR reactions) 197 spanned five orders of magnitude, and the amount of product in a particular sample was 198 determined by interpolation of the cycle threshold $(\mathrm{Ct})$ value. The specificity of reaction

199 was verified by analysis of melting curves and by electrophoresis and sequencing of PCR 200 amplified products. Reactions were performed in triplicate and fluorescence data acquired 201 during the extension phase were normalized to $\beta$-actin, using the delta-delta method (Livak 202 and Schmittgen, 2001).

203

\subsection{Statistics}

Tank average values of growth, feed intake and nutrient retention were used as experimental units in one way analysis of variance followed by Student-Newman-Keuls test at a significance level of $\mathrm{P}<0.05$. Plasma levels of GH and IGF-I were analysed by one

209 and two-way analysis of variance, followed by Student-Newman-Keuls test. Correlation 210 analyses between hepatic transcripts and plasma hormone levels were made by Pearson 211 Product Moment correlations $(\mathrm{P}<0.05)$. 


\section{Results}

Diets $33 \mathrm{VO}$ and 66VO were well accepted by fish, and animals grew rapidly from

21616 to 91-92 g over the course of the 11-week growth study (Table 5). No differences in feed 217 intake (69 to $67.5 \mathrm{~g} /$ fish), daily growth indices (2.66 to $2.68 \%$ ), and feed (1.09 to 1.11 ) or 218 protein (2.21 to 2.25 ) efficiencies were found among control fish (FO) and fish fed 33VO 219 and 66VO diets. Total replacement of fish oil by the vegetable oil blend (diet VO) reduced 220 feed intake $(61 \mathrm{~g} /$ fish) and daily growth indices $(2.43 \%)$ without any significant effect on 221 whole body composition. Nitrogen (35 to $37 \%$ ) and energy (50 to $52 \%$ ) retentions were not 222 altered by dietary treatments, remaining high in all experimental groups. Lipid deposition 223 in mesenteric and liver depots was not affected significantly by dietary treatments, although 224 there was a trend for liver fat to increase with fish oil replacement.

At the end of the growth study, plasma levels of IGF-I were decreased over the course of the post-pandrial period $(\mathrm{P}<0.05)$ (Fig. 1). The highest IGF-I concentration was found in fish fed the $33 \mathrm{VO}$ diet and the lowest in fish fed the VO diet irrespective of sampling time ( 5 to $20 \mathrm{~h}$ postfeeding). Intermediate values were found in control fish and fish fed the 66VO diet.

There was no significant effect of dietary treatment on plasma GH levels (Fig. 2).

231 However, the trend was opposite to that of plasma IGF-I levels. First, the overall plasma 232 GH concentration increased over the course of post-pandrial period $(\mathrm{P}<0.05)$. Secondly, the 233 lowest GH concentration was found in fish fed the $33 \mathrm{VO}$ diet whereas increased values 234 were observed in fish fed the VO diet. Hepatic IGF-I mRNA and plasma levels of IGF-I ( $20 \mathrm{~h}$ postfeeding) were positively 
237 diet with a progressive and significant decrease with additional fish oil replacement, 238 whereas control fish remained at intermediate values (Fig. 3A). IGF-II was expressed at a 239 reduced level and no significant changes were found with dietary treatments, although the 240 trend for IGF-II mRNA was similar to that reported for IGF-I mRNA (Fig. 3B). Hepatic levels of GHR-I mRNA correlated positively with hepatic transcripts of 242 IGF-I and plasma levels of IGF-I (Fig. 4A). Thus, GHR-I mRNA decreased progressively 243 and significantly with the graded replacement of fish oil in fish fed 33VO, 66VO and VO 244 diets. Intermediate values were found in fish fed diet FO. The overall expression of GHR-II 245 was of the same order of magnitude, but no significant changes in GHR transcripts were 246 detected with dietary treatments (Fig. 4B). Muscle expression of IGF-I was lower in comparison to that of IGF-II, and no 248 significant effect of dietary treatments on IGF-I mRNA levels were detected (Fig. 5A). By 249 contrast, IGF-II mRNA was down-regulated in fish fed vegetable oils irrespective of the 250 degree of replacement (Fig. 5B).

251 The overall muscle expression of GHR-I and II was of the same order of magnitude. 252 There was no consistent change on GHR-I mRNAs with dietary treatment (Fig. 6A). By 253 contrast, transcripts of GHR-II were progressively up-regulated in fish fed 33VO and 66VO 254 diets, decreasing thereafter with the $100 \%$ of replacement of fish oil (VO diet) (Fig. 6B). 


\section{Discussion}

The overall growth indices attained in the current work by juvenile gilthead sea bream are higher than those reported for fish of the same age under similar light and temperature conditions (Gómez-Requeni et al., 2003, 2004). This excellent growth performance in all experimental groups could be attributed to improved diet formulation, fish management and culture conditions. However, fish fed the VO diet showed a reduced feed intake and increased liver fat deposition, which is characteristic of a wide range of dietary and hormonal imbalances (see McClain et al., 2004; Avramoglu et al., 2006). Indeed, in juvenile gilthead sea bream fed diets with amino acid imbalances, peripheral lipolysis and tissue expression of lipoprotein lipase are regulated in concert to increase the flux of dietary fatty acids through the liver (Albalat et al., 2005; Saera-Vila et al., 2005a). This can be of special relevance during fasting and over-wintering, and extensive work is now underway for this risk assessment.

Quantitative requirements of essential fatty acids (EFA) appear to vary depending on fish species and growth stage (Sargent et al., 2002). Thus, the biological demand for $n-3$ HUFA was at least $1.3 \%$ for flatfish larvae (Le Milinaire et al., 1983), whereas requirements for juvenile and grower fish were reduced to $0.8 \%$ (Gatesoupe et al., 1977; Lee et al., 2003; Kim and Lee, 2004) and 0.6\% (Lèger et al., 1979), respectively. Similar requirements have been reported for juveniles of European sea bass (Skalli and Robin, 2004) and gilthead sea bream (Kalogeropoulos et al., 1992) fed defatted fish meal and casein-based diets, respectively. Likewise, no detrimental growth effects were found in the present study in fish fed the 66VO diet $(0.9 \%$ EPA + DHA, see Table 3$)$, which indicates that fish oil replacement by alternative vegetable oils is feasible at a high level when EFA 
requirements are covered. Partial fish oil replacement has been conducted successfully in a

281 wide variety of fish species, but this is the first report that maximizes the simultaneous 282 replacement of fish meal and fish oil in practical aquafeeds for fast growing juvenile marine 283 fish.

Fish growth rates vary with season, age and nutritional status and most of these regulatory events are mediated by the GH/IGF axis (Company et al., 2001; Pérez-Sánchez et al., 2002). The wide tissue distribution of GHRs supports the pleiotropic action of GH, although the liver is the most important target tissue of GH and the primary source of systemic IGF-I (endocrine form). In this scenario, changes on the plasma binding capacity of the 33-47 kDa IGF-binding protein represents in rainbow trout an effective mechanism to limit biologically active IGFs (free IGF fraction), keeping growth and GH secretion under control (Gómez-Requeni et al., 2005). Likewise, circulating levels of IGF-I are positively correlated with growth rates and dietary protein levels in Atlantic salmon and 293 Asian sea bass (Dyer et al., 2004). Plasma IGF-I levels are also a good indicator of growth 294 in channel catfish (Silverstein et al., 2000; Li et al., 2006). Similarly, in gilthead sea bream, 295 circulating GH and IGF-I are good markers of nutritional disorders arising from changes in ration size (Pérez-Sánchez et al., 1995, 2002), dietary energy/ratio (Martí-Palanca et al., 1996; Company et al., 1999) and dietary protein source (Gómez-Requeni et al., 2003, 2004). In the current work, the decreased growth of fish fed the VO diet were accordingly paralleled by decreased plasma levels of IGF-I. Since IGF-I mRNA and GHR-I mRNA 300 were also reduced, the reduction in growth could be attributed to a transcriptional defect in 301 the signal transduction of GHR in spite of increased plasma levels of GH. This metabolic 302 feature leads to liver GH resistance as is now widely accepted in several fish species 
303 (Pérez-Sánchez et al., 1995; Beckman et al., 2004; Pierce et al., 2005; Wilkinson et al., 304 2006).

305 Growth in fish fed the VO diet (0.3\% EPA + DHA; see Table 3$)$ was only $90 \%$ of 306 the maximum observed, and there was no mortality in this group over the course of the 307 study. Similar results were reported for juvenile European sea bass fed defatted fish meal 308 diets (Skalli and Robin, 2004), which suggests that marine fish are relatively tolerant to 309 dietary fish oil restriction despite of the recognized essentiality of n-3 HUFA. As stated 310 very early by Watanabe (1982), the triacyglycerol and polar lipid fractions of lipids, both 311 containing adequate amounts of EPA and DHA, have the same EFA value. Takeuchi and 312 Watanabe (1979) have shown that a level of EFA exceeding four times the requirement of 313 rainbow trout leads to poor growth and feed utilisation. Detrimental growth effects have 314 also been reported in juvenile flounder when dietary n-3 HUFA becomes excessive (Kim 315 and Lee, 2004), and 25\% replacement of fish oil by palm oil fatty acid distillate improved 316 weight gain of African catfish ( $\mathrm{Ng}$ et al., 2004). In the present study, growth performance 317 of fish fed FO, $33 \mathrm{VO}$ and $66 \mathrm{VO}$ diets was almost identical, but the balance between 318 endocrine and locally produced IGFs differed depending on dietary treatment. Thus, in fish 319 fed the FO diet, the reduced gene expression and protein production of hepatic IGF-I was apparently compensated by the increased expression of IGF-II at the local tissue level. In mammals, IGF-II mRNA is detected in many fetal tissues but decreases quickly during postnatal development (Daughaday and Rotwein, 1989). Accordingly, IGF-II null mice are small at birth but continue to growth postnatally at a rate similar to wild-type. By contrast, IGF-I null mice born were small and most died in the early neonatal stages. All this strongly supports the key role of IGF-I during prenatal and postnatal growth. However, 326 hepatic IGF-I is not crucial for postnatal growth in mammals, and liver-specific IGF-I 
327 knockout mice show normal growth due to the compensatory action of autocrine/paracrine

328 IGF-I (see Le Roith et al., 2001a,b). As postulated above in the present study, 329 compensatory increases of systemic IGF-I also occur in fish but, in this case, most of these 330 effects are dependent on local IGF-II. Indeed, substantial amounts of IGF-II are expressed 331 later in life in a wide range of fish species, including common carp (Vong et al., 2003), 332 rainbow trout (Chauvigné et al., 2003), Nile tilapia (Caelers et al., 2004), channel catfish 333 (Peterson et al., 2004), and gilthead sea bream as already evidenced in previous studies 334 (Duguay et al., 1996; Radaelli et al., 2003) and confirmed here. Furthermore, as found for 335 IGF-I, the main site for fish IGF-II expression is the liver, but in contrast to IGF-I, other 336 organs such as skeletal muscle also express quite high levels of IGF-II mRNA. Thus, fast 337 growing families of channel catfish express hepatic and muscle IGF-II at a high rate 338 (Peterson et al., 2004), and the growth spurt of juvenile rainbow trout during refeeding 339 could be mediated by muscle IGF-II (Chauvigné et al., 2003). Accordingly, it is reasonable 340 to assume that IGF-II acts in fish as an important growth-promoting factor through all the 341 life cycle, although most of these regulatory capabilities might have been lost during the 342 evolution of higher vertebrates.

To our knowledge, the precise mechanism(s) regulating the relative contribution of 344 systemic and local IGFs on fish growth remains unexplored. However, we suspect that 345 some results of the current study could be mediated by factors other than dietary fatty acids. 346 One of these factors might be the reduction in unwanted feed-borne lipid soluble 347 contaminants with the reduction in fish oil level. This assumption is based on our 348 complementary data (unpublished results) showing that dioxin-like PCBs in the FO diet 349 were markedly reduced with the graded fish oil replacement, as shown in previous studies 350 (Berntssen et al., 2005; Bethune et al., 2006). Experimental evidence also indicates that the 
351 wasting syndrome caused in mice by 3-methylcholanthrene is mediated by aromatic 352 hydrocarbon receptors (AHRs) that interact with xenobiotic responsive elements (XREs) in 353 the GHR promoter, disrupting the liver GH signalling pathway (IGF production) (Nukaya 354 et al., 2004). Likewise, several XREs have been identified in the 5 '-flanking region of 355 gilthead sea bream GHR-I (unpublished results), although further studies are needed to 356 determine whether these cis-regulatory elements are functional in fish. Besides, it has been 357 proven that expression levels of GH and prolactin (PRL) are regulated in rainbow trout by 358 persistent xenoestrogens and antiestrogenic pollutants (Elango et al., 2006), and both 359 estradiol and 4-nonylphenol suppress growth and plasma levels of IGF-I in juvenile 360 Atlantic salmon (Arsenault et al., 2004). It is not surprising, therefore, that gonadal steroids 361 modulate hepatic production of IGF-I and IGFBPs in tilapia (Riley et al., 2004) and coho 362 salmon (Larsen et al., 2004). All this provides regulatory mechanisms for dimorphic growth 363 patterns in fish, but at the same time makes the GH/IGF axis more vulnerable to potential 364 anthropogenic feed-borne contaminants.

365 Transgenic models in mice also indicate that major effects of GH on growth are 366 dependent on IGF-I expression, which requires intact insulin and IGF-I receptor signalling 367 in skeletal muscle (Kim et al., 2005). However, GH regulates other mitogenic factors, and 368 there is now experimental evidence supporting the up-regulated expression of GHRs during 369 muscle repair and maintenance (Casse et al., 2003). In fish, it is believed that genetic 370 duplication and divergence of two GHR subtypes (GHR type I and II) would take place on 371 an early ancestor of fish lineage (Saera-Vila et al., 2005b; Jiao et al., 2006). GHR-I was 372 first described in non-salmonid fish (Calduch-Giner et al., 2001), conserving most of the 373 structural features of mammalian GHRs. By contrast, GHR-II (also named somatolactin 374 receptor by Fukada et al., 2005) is unique to teleosts and encompasses most of the 
375 published GHR sequences of salmonid fish. These two GHR subtypes are conserved in a

376 wide range of fish species, although apparent silencing and/or genomic loss of GHR-II was

377 reported in the flatfish lineage with the occurrence of truncated variants of GHR-I (Pérez-

378 Sánchez et al., 2002; Saera-Vila et al., 2005b). In this scenario, the current study confirms

379 and extends the notion that major GH effects on growth and hepatic IGF expression are

380 mediated by GHR-I in gilthead sea bream. By contrast, GHR-II emerges as a more

381 constitutive gene that does not necessarily require intact IGF-pathways to exert a protective

382 and/or growth promoting action. This is consistent with the up-regulated expression of

383 GHR-II in skeletal muscle of fish fed the 66VO diet. In this way, we previously reported

384 that GHR-II is up-regulated in the skeletal muscle of fasted juvenile gilthead sea bream

385 (Calduch-Giner et al., 2003). Similarly, Fukada et al. (2004) indicated that transcript levels

386 of GHR-II are not related in masu salmon to decreased expression of hepatic IGF-I during

387 fasting.

388 In summary, our data strongly support that combined replacement at a high level of

389 fish meal and oil is possible in diets of gilthead sea bream, contributing to the development

390 of sustainable aquafeeds. Data also bring new insights on the compensatory regulation of

391 systemic and local components of the GH/IGF axis (see Fig. 7 for a comprehensive survey)

392 in growing fish. Additional studies are underway to further explore the potential of

393 practical diets low in marine ingredients over the full cycle of gilthead sea bream farming,

394 addressing also issues related to potential feed-borne endocrine disruption of GH/IGF axis. 


\section{Acknowledgements}

396

397 This research was funded by EU (FOOD-CT-2006-16249; Sustainable Aquafeeds to 398 Maximise the Health Benefits of Farmed Fish for Consumers, AQUAMAX), and Spanish 399 (AGL2004-06319-CO2) projects. A.S-V was recipient of a PhD fellowship from the 400 Diputación Provincial de Castellón. The authors are grateful to M.A. Gónzalez for excellent 401 technical assistance in real-time PCR assays. 


\section{References}

403

404 Albalat, A., Gómez-Requeni, P., Rojas, P., Médale, F., Kaushik, S., Vianen, J., Van den 405 Thillart, G., Gutiérrez, J., Pérez-Sánchez, J., Navarro, I., 2005. Nutritional and hormonal 406 control of lipolysis in isolated gilthead seabream (Sparus aurata) adipocytes. Am. J. 407 Physiol. 289, R259-R265.

408 Arsenault, J.T.M., Fairchild, W.L., MacLatchy, D.L., Burridge, L., Haya, K., Brown, S.B., 409 2004. Effects of water-borne 4-nonylphenol and 17 $\beta$-estradiol exposures during parr-smolt 410 transformation on growth and plasma IGF-I of Atlantic salmon (Salmo salar L.). Aquat. 411 Toxicol. 66, 255-265.

412 Avramoglu, R.K., Basciano, H., Adeli, K., 2006. Lipid and lipoprotein dysregulation in 413 insulin resistant states. Clin. Chim. Acta 368, 1-19.

414 Basha, S.M.M., Roberts, R.M., 1977. A simple colorimetric method for the determination 415 of tryptophan. Anal. Biochem. 77, 378-386.

416 Beckman, B.R., Shimizu, M., Gadberry, B.A., Parkins, P.J., Cooper, K.A., 2004. The effect 417 of temperature change on the relations among plasma IGF-I, 41-kDa IGFBP, and growth 418 rate in postsmolt coho salmon. Aquaculture 241, 601-619.

419 Bell, J.G., McGhee, F., Campbell, P.J., Sargent, J.R., 2003. Rapeseed oil as an alternative 420 to marine fish oil in diets of post-smolt Atlantic salmon (Salmo salar): changes in flesh 421 fatty acid composition and effectiveness of subsequent fish oil "wash out". Aquaculture $422 \quad 218,515-528$. 
Berntssen, M.H.G., Lundebye, A.-K., Torstensen, B.E., 2005. Reducing the levels of dioxins and dioxin-like PCBs in farmed Atlantic salmon by substitution of fish oil with vegetable oil in the feed. Aquacult. Nutr. 11, 219-231.

Bethune, C., Seierstad, S.L., Seljeflot, I., Johansen, O., Arnesen, H., Meltzer, H.M., Rosenlund, G., Frøyland, L., Lundebye, A.K., 2006. Dietary intake of differently fed salmon: a preliminary study on contaminants. Eur. J. Clin. Invest. 36, 193-201.

Bragadóttir, M., Palmadóttir, H., Kristbergsson, K., 2004. Composition and chemical changes during storage of fish meal from capelin (Mallotus villosus). J. Agric. Food Chem. $52,1572-1580$.

Bransden, M.P., Carter, C.G., Nichols, P.D., 2003. Replacement of fish oil with sunflower oil in feeds for Atlantic salmon (Salmo salar L.): effect on growth performance, tissue fatty acid composition and disease resistance. Comp. Biochem. Physiol. 135B, 611-625.

Caelers, A., Berishvili, G., Meli, M.L., Eppler, E., Reinecke, M., 2004. Establishment of a real-time RT-PCR for the determination of absolute amounts of IGF-I and IGF-II gene expression in liver and extrahepatic sites of the tilapia. Gen. Comp. Endocrinol. 137, 196204.

Calduch-Giner, J.A., Duval, H., Chesnel, F., Boeuf, G., Pérez-Sánchez, J., Boujard, D., 2001. Fish growth hormone receptor: molecular characterization of two membraneanchored forms. Endocrinology 142, 3269-3273.

Calduch-Giner, J.A., Mingarro, M., Vega-Rubín de Celis, S., Boujard, D., Pérez-Sánchez, J., 2003. Molecular cloning and characterization of gilthead sea bream (Sparus aurata) 
444 growth hormone receptor (GHR). Assessment of alternative splicing. Comp. Biochem. 445 Physiol. 136B, 1-13.

446 Casse, A.H., Desplanches, D., Mayet-Sornay, M.H., Raccurt, M., Jegou, S., Morel, G., 447 2003. Growth hormone receptor expression in atrophying muscle fibers of rats. $448 \quad$ Endocrinology 144, 3692-3697.

449 Chauvigné, F., Gabillard, J.C., Weil, C., Rescan, P.Y., 2003. Effect of refeeding on IGFI, 450 IGFII, IGF receptors, FGF2, FGF6, and myostatin mRNA expression in rainbow trout 451 myotomal muscle. Gen. Comp. Endocrinol. 132, 209-215.

452 Christie, W.W., 1982. Lipid Analysis. Isolation, Separation, Identification and Structural 453 Analysis of Lipids. Pergamon Press, Oxford, 207pp.

454 Company, R., Calduch-Giner, J.A., Kaushik, S., Pérez-Sánchez, J., 1999. Growth 455 performance and adiposity in gilthead sea bream (Sparus aurata): risks and benefits of high 456 energy diets. Aquaculture 171, 279-292.

457 Company, R., Astola, A., Pendón, C., Valdivia, M.M., Pérez-Sánchez, J., 2001. 458 Somatotropic regulation of fish growth and adiposity: growth hormone $(\mathrm{GH})$ and 459 somatolactin (SL) relationship. Comp. Biochem. Physiol. 130C, 435-445.

460 Daughaday, W.H., Rotwein, P., 1989. Insulin-like growth factors I and II. Peptide, 461 messenger ribonucleic acid and gene structures, serum, and tissue concentrations. Endocr. 462 Rev. 10, 68-91. 
463 Duguay, S.J., Lai-Zhang, J., Steiner, D.F., Funkenstein, B., Chan, S.J., 1996.

464 Developmental and tissue-regulated expression of IGF-I and IGF-II mRNAs in Sparus 465 aurata. J. Mol. Endocrinol. 16, 123-132.

466 Dyer, A.R., Barlow, C.G., Bransden, M.P., Carter, C.G., Glencross, B.D., Richardson, N., 467 Thomas, P.M., Williams, K.C., Carragher, J.F., 2004. Correlation of plasma IGF-I 468 concentrations and growth rate in aquacultured finfish: a tool for assessing the potential of 469 new diets. Aquaculture 236, 583-592.

470 Elango, A., Shepherd, B., Chen, T.T., 2006. Effects of endocrine disrupters on the 471 expression of growth hormone and prolactin mRNA in the rainbow trout pituitary. Gen. 472 Comp. Endocrinol. 145, 116-127.

473 FAO, Food and Agriculture Organization, 2004. The state of world fisheries and 474 aquaculture. Fisheries department, Rome, 168pp.

475 Francis, D.S., Turchini, G.M., Jones, P.L., De Silva, S.S., 2006. Effects of dietary oil 476 source on growth and fillet fatty acid composition of Murray cod, Maccullochella peelii 477 peelii. Aquaculture 253, 547-556.

478 Fukada, H., Ozaki, Y., Pierce, A.L., Adachi, S., Yamauchi, K., Hara, A., Swanson, P., 479 Dickhoff, W.W., 2004. Salmon growth hormone receptor: molecular cloning, ligand 480 specificity, and response to fasting. Gen. Comp. Endocrinol. 139, 61-71.

481 Fukada, H., Ozaki, Y., Pierce, A.L., Adachi, S., Yamauchi, K., Hara, A., Swanson, P., 482 Dickhoff, W.W., 2005. Identification of the salmon somatolactin receptor, a new member 483 of the cytokine receptor family. Endocrinology 146, 2354-2361. 
484 Gatesoupe, F.J., Lèger, C., Boudon, M., Métailler, R., Luquet, P., 1977. Lipid feeding of 485 turbot (Scophthalmus maximus L). 2. Influence on growth of supplementation with methyl 486 esters of linolenic acid and fatty acids of $\omega-9$ series. Ann. Hydrobiol. 8, 247-254.

487 Gómez-Requeni, P., Mingarro, M., Kirchner, S., Calduch-Giner, J.A., Médale, F., Corraze, 488 G., Panserat, S., Martin, S.A.M., Houlihan, D.F., Kaushik, S.J., Pérez-Sánchez, J., 2003. 489 Effects of dietary amino acid profile on growth performance, key metabolic enzymes and 490 somatotropic axis responsiveness of gilthead sea bream (Sparus aurata). Aquaculture 220, $491 \quad 749-767$.

492 Gómez-Requeni, P., Mingarro, M., Calduch-Giner, J.A., Médale, F., Martin, S.A.M., 493 Houlihan, D.F., Kaushik, S., Pérez-Sánchez, J., 2004. Protein growth performance, amino 494 acid utilisation and somatotropic axis responsiveness to fish meal replacement by plant 495 protein sources in gilthead sea bream (Sparus aurata). Aquaculture 232, 493-510.

496 Gómez-Requeni, P., Calduch-Giner, J., Vega-Rubín de Celis, S., Médale, F., Kaushik, S.J., 497 Pérez-Sánchez, J., 2005. Regulation of the somatotropic axis by dietary factors in rainbow 498 trout (Oncorhynchus mykiss). Br. J. Nutr. 94, 353-361.

499 Hardy, M.L., 2004. A comparison of the fish bioconcentration factors for brominated flame 500 retardants with their nonbrominated analogues. Environ. Toxicol. Chem. 23, 656-661.

501 Izquierdo, M.S., Montero, D., Robaina, L., Caballero, M.J., Rosenlund, G., Ginés, R., 2005. 502 Alterations in fillet fatty acid profile and flesh quality in gilthead seabream (Sparus aurata) 503 fed vegetable oils for a long term period. Recovery of fatty acid profiles by fish oil feeding. 504 Aquaculture 250, 431-444. 
505 Jacobs, M.N., Covaci, A., Schepens, P., 2002. Investigation of persistent organic pollutants 506 in farmed Atlantic salmon (Salmo salar), salmon aquaculture feed, and fish oil components 507 of the feed. Environ. Sci. Technol. 36, 2797-2805.

508 Jiao, B.W., Huang, X.G., Chan, C.B., Zhang, L., Wang, D.S., Cheng, C.H.K., 2006. The 509 co-existence of two growth hormone receptors in teleost fish and their differential signal 510 transduction, tissue distribution and hormonal regulation of expression in seabream. J. Mol. 511 Endocrinol. 36, 23-40.

512 Kalogeropoulos, N., Alexis, M.N., Henderson, R.J., 1992. Effects of dietary soybean and 513 cod-liver oil levels on growth and body composition of gilthead bream (Sparus aurata). 514 Aquaculture 104, 293-308.

515 Kaushik, S.J., 1998. Whole body amino acid composition of European seabass 516 (Dicentrarchus labrax), gilthead seabream (Sparus aurata) and turbot (Psetta maxima) 517 with an estimation of their IAA requirement profiles. Aquat. Living Resour. 11, 355-358.

518 Kim, K.D., Lee, S.M., 2004. Requirement of dietary n-3 highly unsaturated fatty acids for 519 juvenile flounder (Paralichthys olivaceus). Aquaculture 229, 315-323.

520 Kim, H., Barton, E., Muja, N., Yakar, S., Pennisi, P., LeRoith, D., 2005. Intact insulin and 521 insulin-like growth factor-I receptor signaling is required for growth hormone effects on 522 skeletal muscle growth and function in vivo. Endocrinology 146, 1772-1779.

523 Larsen, D.A., Shimizu, M., Cooper, K.A., Swanson, P., Dickhoff, W.W., 2004. Androgen 524 effects on plasma GH, IGF-I, and 41-kDa IGFBP in coho salmon (Oncorhynchus kisutch). 525 Gen. Comp. Endocrinol. 139, 29-37. 
526 Le Milinaire, C., Gatesoupe, F.J., Stephan, G., 1983. Quantitative needs for n-3 series poly527 unsaturated long chain fatty acids requirement in turbot (Scophthalmus maximus) larvae. 528 C.R. Acad. Sci. Paris 296, 917-920.

529 Le Roith, D., Bondy, C., Yakar, S., Liu, J.L., Butler, A., 2001a. The somatomedin 530 hypothesis: 2001. Endocr. Rev. 22, 53-74.

531 Le Roith, D., Scavo, L., Butler, A., 2001b. What is the role of circulating IGF-I? Trends 532 Endocrinol. Metab. 12, 48-52.

533 Lee, S.M., Lee, J.H., Kim, K.D., 2003. Effect of dietary essential fatty acids on growth, 534 body composition and blood chemistry of juvenile starry flounder (Platichthys stellatus). 535 Aquaculture 225, 269-281.

536 Lèger, C., Gatesoupe, F.J., Métailler, R., Luquet, P., Fremont, L., 1979. Effect of dietary 537 fatty acids differing by chain lengths and $\omega$ series on the growth and lipid composition of 538 turbot Scophthalmus maximus L. Comp. Biochem. Physiol. 64B, 345-350.

539 Li, M.H., Peterson, B.C., Janes, C.L., Robinson, E.H., 2006. Comparison of diets 540 containing various fish meal levels on growth performance, body composition, and insulin541 like growth factor-I of juvenile channel catfish Ictalurus punctatus of different strains. 542 Aquaculture 253, 628-635.

543 Livak K.J., Schmittgen T.D., 2001. Analysis of relative gene expression data using real544 time quantitative PCR and the $2^{-\Delta \Delta \mathrm{Ct}}$ method. Methods 25, 402-408. 
545 Martí-Palanca, H., Martínez-Barberá, J.P., Pendón, C., Valdivia, M.M., Pérez-Sanchez, J., 546 Kaushik, S., 1996. Growth hormone as a function of age and dietary protein: energy ratio in 547 a marine teleost, the gilthead sea bream (Sparus aurata). Growth Regul. 6, 253-259.

548 Martínez-Barberá, J.P., Pendón, C., Martí-Palanca, H., Calduch-Giner, J.A., Rodríguez, 549 R.B., Valdivia, M.M., Pérez-Sánchez, J., 1995. The use of recombinant gilthead sea bream 550 (Sparus aurata) growth hormone for radioiodination and standard preparation in 551 radioimmunoassay. Comp. Biochem. Physiol. 110A, 335-340.

552 McClain, C.J., Mokshagundam, S.P., Barve, S.S., Song, Z., Hill, D.B., Chen, T., Deaciuc, 553 I., 2004. Mechanisms of non-alcoholic steatohepatitis. Alcohol 34, 67-79.

554 Montero, D., Robaina, L., Caballero, M.J., Ginés, R., Izquierdo, M.S., 2005. Growth, feed 555 utilization and flesh quality of European sea bass (Dicentrarchus labrax) fed diets 556 containing vegetable oils: A time-course study on the effect of a re-feeding period with a $557 \quad 100 \%$ fish oil diet. Aquaculture 248, 121-134.

558 Mourente, G., Dick, J.R., Bell, J.G., Tocher, D.R., 2005. Effect of partial substitution of 559 dietary fish oil by vegetable oils on desaturation and $\beta$-oxidation of $\left[1-{ }^{14} \mathrm{C}\right] 18: 3 \mathrm{n}-3$ (LNA) 560 and $\left[1-{ }^{14} \mathrm{C}\right] 20: 5 \mathrm{n}-3$ (EPA) in hepatocytes and enterocytes of European sea bass 561 (Dicentrarchus labrax L.). Aquaculture 248, 173-186.

562 Mourente, G., Bell, J.G., 2006. Partial replacement of dietary fish oil with blends of 563 vegetable oils (rapeseed, linseed and palm oils) in diets for European sea bass 564 (Dicentrarchus labrax L.) over the whole production cycle: effects on flesh and liver fatty 565 acid composition and effectiveness of a fish oil finishing diet. Comp. Biochem. Physiol. $566145 \mathrm{~B}, 389-399$. 
567 Ng, W.K., Wang, Y., Ketchimenin, P., Yuen, K.H., 2004. Replacement of dietary fish oil 568 with palm fatty acid distillate elevates tocopherol and tocotrienol concentrations and 569 increases oxidative stability in the muscle of African catfish, Clarias gariepinus. 570 Aquaculture 233, 423-437.

571 Nukaya, M., Takahashi, Y., González, F.J., Kamataki, T., 2004. Aryl hydrocarbon receptor572 mediated suppression of GH receptor and Janus kinase 2 expression in mice. FEBS Lett. $573558,96-100$.

574 Opstvedt, J., Nygård, E., Samuelsen, T.A., Venturini, G., Luzzana, U., Mundheim, H., 575 2003. Effect on protein digestibility of different processing conditions in the production of 576 fish meal and fish feed. J. Sci. Food Agric. 83, 775-782.

577 Pérez-Sánchez, J., Le Bail, P.Y., 1999. Growth hormone axis as marker of nutritional status 578 and growth performance in fish. Aquaculture 177, 117-128.

579 Pérez-Sánchez, J., Martí-Palanca, H., Kaushik, S.J., 1995. Ration size and protein intake 580 affect circulating growth hormone concentration, hepatic growth hormone binding and 581 plasma insulin-like growth factor-I immunoreactivity in a marine teleost, the gilthead 582 bream (Sparus aurata). J. Nutr. 125, 546-552.

583 Pérez-Sánchez, J., Calduch-Giner, J.A., Mingarro, M., Vega-Rubín de Celis, S., Gómez584 Requeni, P., Saera-Vila, A., Astola, A., Valdivia, M.M., 2002. Overview of fish growth 585 hormone family. New insights in genomic organization and heterogeneity of growth 586 hormone receptors. Fish Physiol. Biochem. 27, 243-258. Special Issue, E.M. Plisetskaya 587 (Ed.), Fish Growth and Metabolism. Experimental, Nutritional and Hormonal Regulation, 588 published in 2004. 
589 Peterson, B.C., Waldbieser, G.C., Bilodeau, L., 2004. IGF-I and IGF-II mRNA expression 590 in slow and fast growing families of USDA103 channel catfish (Ictalurus punctatus). 591 Comp. Biochem. Physiol. 139A, 317-323.

592 Pierce, A.L., Shimizu, M., Beckman, B.R., Baker, D.M., Dickhoff, W.W., 2005. Time 593 course of the GH/IGF axis response to fasting and increased ration in chinook salmon 594 (Oncorhynchus tshawytscha). Gen. Comp. Endocrinol. 140, 192-202.

595 Radaelli, G., Patruno, M., Maccatrozzo, L., Funkenstein, B., 2003. Expression and cellular 596 localization of insulin-like growth factor-II protein and mRNA in Sparus aurata during 597 development. J. Endocrinol. 178, 285-299.

598 Regost, C., Arzel, J., Robin, J., Rosenlund, G., Kaushik, S.J., 2003. Total replacement of 599 fish oil by soybean or linseed oil with a return to fish oil in turbot (Psetta maxima): 1. 600 Growth performance, flesh fatty acid profile, and lipid metabolism. Aquaculture 217, 465601482.

602 Richard, N., Kaushik, S., Larroquet, L., Panserat, S., Corraze, G., 2006a. Replacing dietary 603 fish oil by vegetable oils has little effects on lipogenesis, lipid transport and tissue lipid 604 uptake in rainbow trout (Oncorhynchus mykiss). Br. J. Nutr. 96, 299-309.

605 Richard, N., Mourente, G., Kaushik, S., Corraze, G., 2006b. Replacement of a large portion 606 of fish oil by vegetable oils does not affect lipogenesis, lipid transport and tissue lipid 607 uptake in European sea bass (Dicentrarchus labrax L.). Aquaculture 261, 1077-1087.

608 Riley, L.G., Hirano, T., Grau, E.G., 2004. Estradiol-17 $\beta$ and dihydrotestosterone 609 differentially regulate vitellogenin and insulin-like growth factor-I production in primary 
610 hepatocytes of the tilapia Oreochromis mossambicus. Comp. Biochem. Physiol. 138C, 177611186.

612 Saera-Vila, A., Calduch-Giner, J.A., Gómez-Requeni, P., Médale, F., Kaushik, S., Pérez613 Sánchez, J., 2005a. Molecular characterization of gilthead sea bream (Sparus aurata) 614 lipoprotein lipase. Transcriptional regulation by season and nutritional condition in skeletal 615 muscle and fat storage tissues. Comp. Biochem. Physiol. 142B, 224-232.

616 Saera-Vila, A., Calduch-Giner, J.A., Pérez-Sánchez, J., 2005b. Duplication of growth 617 hormone receptor (GHR) in fish genome: gene organization and transcriptional regulation 618 of GHR type I and II in gilthead sea bream (Sparus aurata). Gen. Comp. Endocrinol. 142, $619 \quad 193-203$.

620 Sargent, J., McEvoy, L., Estevez, A., Bell, G., Bell, M., Henderson, J., Tocher, D., 1999. 621 Lipid nutrition of marine fish during early development: current status and future 622 directions. Aquaculture 179, 217-229.

623 Sargent, J., Tocher, D.R., Bell, J.G., 2002. The lipids. In: Halver, J.E., Hardy, R.W. (Eds.), 624 Fish Nutrition. Academic Press, San Diego, pp. 181-257.

625 Silverstein, J.T., Wolters, W.R., Shimizu, M., Dickhoff, W.W., 2000. Bovine growth 626 hormone treatment of channel catfish: strain and temperature effects on growth, plasma 627 IGF-I levels, feed intake and efficiency and body composition. Aquaculture 190, 77-88.

628 Sitjà-Bobadilla, A., Peña-Llopis, S., Gómez-Requeni, P., Médale, F., Kaushik, S., Pérez629 Sánchez, J., 2005. Effect of fish meal replacement by plant protein sources on non-specific 
630 defence mechanisms and oxidative stress in gilthead sea bream (Sparus aurata). 631 Aquaculture 249, 387-400.

632 Skalli, A., Robin, J.H., 2004. Requirement of n-3 long chain polyunsaturated fatty acids for 633 European sea bass (Dicentrarchus labrax) juveniles: growth and fatty acid composition. 634 Aquaculture 240, 399-415.

635 Takeuchi, T., Watanabe, T., 1979. Effect of excess amounts of essential fatty acids on 636 growth of rainbow trout. Bull. Jpn. Soc. Sci. Fish. 45, 1517-1519.

637 Torstensen, B.E., Froyland, L., Ørnsrud, R., Lie, Ø., 2004. Tailoring of a cardioprotective 638 muscle fatty acid composition of Atlantic salmon (Salmo salar) fed vegetable oils. Food 639 Chem. 87, 567-580.

640 Torstensen, B.E., Bell, J.G., Rosenlund, G., Henderson, R.J., Graff, I.E., Tocher, D.R., Lie, 641 Ø., Sargent, J.R., 2005. Tailoring of Atlantic salmon (Salmo salar L.) flesh lipid 642 composition and sensory quality by replacing fish oil with vegetable oil blend. J. Agric. $643 \quad$ Food Chem. 53, 10166-10178.

644 Vega-Rubín de Celis, S., Gómez-Requeni, P., Pérez-Sánchez, J., 2004. Production and 645 characterization of recombinantly derived peptides and antibodies for accurate 646 determinations of somatolactin, growth hormone and insulin-like growth factor-I in 647 European sea bass (Dicentrarchus labrax). Gen. Comp. Endocrinol. 139, 266-277.

648 Vong, Q.P., Chan, K.M., Leung, K., Cheng, C.H.K., 2003. Common carp insulin-like 649 growth factor-I gene: complete nucleotide sequence and functional characterization of the $650 \quad$ 5'-flanking region. Gene 322, 145-156. 
651 Watanabe, T., 1982. Lipid nutrition in fish. Comp. Biochem. Physiol. 73B, 3-15.

652 Wilkinson, R.J., Porter, M., Woolcott, H., Longland, R., Carragher, J.F., 2006. Effects of 653 aquaculture related stressors and nutritional restriction on circulating growth factors $(\mathrm{GH}$, 654 IGF-I and IGF-II) in Atlantic salmon and rainbow trout. Comp. Biochem. Physiol. 145A, $655 \quad 214-224$. 
656 Table 1. Ingredients and chemical composition of experimental diets.

\begin{tabular}{|c|c|c|c|c|}
\hline Ingredient $(\mathrm{g} / \mathrm{kg})$ & $\mathrm{FO}$ & $33 \mathrm{VO}$ & $66 \mathrm{VO}$ & VO \\
\hline Fish meal (CP 70\%) $^{1}$ & 15 & 15 & 15 & 15 \\
\hline CPSP $90^{2}$ & 5 & 5 & 5 & 5 \\
\hline Corn gluten meal & 40 & 40 & 40 & 40 \\
\hline Soybean meal & 14.3 & 14.3 & 14.3 & 14.3 \\
\hline Extruded wheat & 4 & 4 & 4 & 4 \\
\hline Fish oil $^{3}$ & 15.1 & 10.1 & 5.1 & 0 \\
\hline Rapeseed oil & 0 & 0.85 & 1.7 & 2.58 \\
\hline Linseed oil & 0 & 2.9 & 5.8 & 8.8 \\
\hline Palm oil & 0 & 1.25 & 2.5 & 3.8 \\
\hline Soya lecithin & 1 & 1 & 1 & 1 \\
\hline Binder (sodium alginate) & 1 & 1 & 1 & 1 \\
\hline Mineral premix ${ }^{4}$ & 1 & 1 & 1 & 1 \\
\hline Vitamin premix ${ }^{5}$ & 1 & 1 & 1 & 1 \\
\hline $\mathrm{CaHPO}_{4} .2 \mathrm{H}_{2} \mathrm{O}(18 \% \mathrm{P})$ & 2 & 2 & 2 & 2 \\
\hline L-Lysine & 0.55 & 0.55 & 0.55 & 0.55 \\
\hline
\end{tabular}

Proximate composition

\begin{tabular}{lcccc} 
Dry matter (DM, \%) & 93.4 & 94.2 & 94.8 & 95.4 \\
Crude protein (\% DM) & 48.9 & 48.7 & 49.0 & 48.6 \\
Crude fat (\% DM) & 22.2 & 22.3 & 22.1 & 22.3 \\
Ash (\% DM) & 6.5 & 6.6 & 6.6 & 6.4 \\
EPA + DHA (\% DM) & 2.3 & 1.6 & 0.9 & 0.3 \\
Gross energy (kJ/g DM) & 24.7 & 24.7 & 24.6 & 24.5 \\
\hline
\end{tabular}

${ }^{1}$ Fish meal (Scandinavian LT)

$659{ }^{2}$ Fish soluble protein concentrate (Sopropêche, France)

$660{ }^{3}$ Fish oil (Sopropêche, France)

$661{ }^{4}$ Supplied the following ( $\mathrm{mg} / \mathrm{kg}$ diet, except as noted): calcium carbonate $(40 \% \mathrm{Ca}) 2.15 \mathrm{~g}$, 662 magnesium hydroxide $(60 \% \mathrm{Mg}) 1.24 \mathrm{~g}$, potassium chloride $0.9 \mathrm{~g}$, ferric citrate $0.2 \mathrm{~g}$, 663 potassium iodine $4 \mathrm{mg}$, sodium chloride $0.4 \mathrm{~g}$, calcium hydrogen phosphate $50 \mathrm{~g}$, copper 664 sulphate 0.3 , zinc sulphate 40 , cobalt sulphate 2 , manganese sulphate 30 , sodium selenite 6650.3

$666{ }^{5}$ Supplied the following (mg / $\mathrm{kg}$ diet): retinyl acetate 2.58, DL-cholecalciferol 0.037, DL- $\alpha$ 667 tocopheryl acetate 30 , menadione sodium bisulphite 2.5 , thiamin 7.5 , riboflavin 15 , 668 pyridoxine 7.5 , nicotinic acid 87.5 , folic acid 2.5 , calcium pantothenate 2.5 , vitamin $\mathrm{B}_{12}$ 6690.025 , ascorbic acid 250, inositol 500, biotin 1.25 and choline chloride 500 
670 Table 2. Amino acid, mineral and trace element 671 composition of the diets along with data on amino acid 672 needs (Kaushik 1998).

\begin{tabular}{|c|c|c|c|}
\hline \multirow{2}{*}{ Amino acid (\%) } & \multirow{3}{*}{$\frac{\mathrm{FO} / \mathrm{VO} \text { diets }}{2.18}$} & \multicolumn{2}{|r|}{673} \\
\hline & & Needs & 674 \\
\hline Arg & & 1.86 & $\begin{array}{l}675 \\
676\end{array}$ \\
\hline His & 0.93 & 0.86 & 677 \\
\hline Ile & 1.92 & 1.11 & 678 \\
\hline Leu & 5.58 & 1.73 & 679 \\
\hline Lys & 2.42 & 2.23 & 680 \\
\hline Met & 1.05 & & $\begin{array}{l}681 \\
682\end{array}$ \\
\hline Cys & 0.61 & & 683 \\
\hline Cys + Met & 1.66 & 1.24 & 684 \\
\hline Phe & 2.47 & & 685 \\
\hline Tyr & 2 & & $\begin{array}{l}686 \\
687\end{array}$ \\
\hline Phe + Tyr & 4.47 & 2.23 & 688 \\
\hline Thr & 1.69 & 0.99 & 689 \\
\hline $\operatorname{Trp}$ & 0.39 & 0.25 & 690 \\
\hline Val & 2.15 & 1.49 & $\begin{array}{l}691 \\
692\end{array}$ \\
\hline Ser & 2.23 & & 693 \\
\hline Ala & 3.36 & & 694 \\
\hline Asp & 3.69 & & 695 \\
\hline Glu & 8.37 & & 696 \\
\hline Gly & 2.01 & & $\begin{array}{l}691 \\
698\end{array}$ \\
\hline Pro & 3.02 & & 699 \\
\hline & & & 700 \\
\hline Minerals $(\%, \mu \mathrm{g} / \mathrm{g})$ & & & 701 \\
\hline Phosphorous (\%) & 1.08 & & $\begin{array}{l}102 \\
703\end{array}$ \\
\hline Magnesium (\%) & 0.18 & & 704 \\
\hline Potassium (\%) & 0.74 & & 705 \\
\hline Iron $(\mu \mathrm{g} / \mathrm{g})$ & 216 & & 706 \\
\hline Copper $(\mu \mathrm{g} / \mathrm{g})$ & 15 & & $\begin{array}{l}707 \\
708\end{array}$ \\
\hline Manganese $(\mu \mathrm{g} / \mathrm{g})$ & 19 & & 709 \\
\hline Zinc $(\mu \mathrm{g} / \mathrm{g})$ & 50 & & 710 \\
\hline Selenium $(\mu \mathrm{g} / \mathrm{g})$ & 0.9 & & 711 \\
\hline
\end{tabular}


717 Table 3. Fatty acid composition of experimental diets (\% total FAME). Values

718 are means of two determinations; $\operatorname{tr}=$ trace value $<0.05$

\begin{tabular}{|c|c|c|c|c|}
\hline Fatty acid & FO & $33 \mathrm{VO}$ & $66 \mathrm{VO}$ & $\mathrm{VO}$ \\
\hline $14: 0$ & 5.02 & 3.70 & 1.89 & 0.59 \\
\hline $15: 0$ & 0.35 & 0.22 & 0.13 & 0.12 \\
\hline $16: 0$ & 16.7 & 16.9 & 16.9 & 16.7 \\
\hline $16: 1 n-7$ & 4.63 & 2.97 & 1.96 & 0.76 \\
\hline $16: 1 n-9$ & 0.22 & 0.15 & $\operatorname{tr}$ & $\operatorname{tr}$ \\
\hline $16: 3$ & 0.49 & 0.35 & 0.26 & 0.14 \\
\hline $16: 3 n-3$ & 0.19 & 0.13 & 0.08 & $\operatorname{tr}$ \\
\hline $16: 4$ & 0.40 & 0.29 & 0.17 & $\operatorname{tr}$ \\
\hline $17: 0$ & 0.41 & 0.29 & 0.23 & 0.10 \\
\hline $18: 0$ & 2.55 & 2.92 & 3.43 & 3.73 \\
\hline $18: 1 n-9$ & 12.5 & 17.5 & 21.9 & 25.9 \\
\hline $18: 1 n-7$ & 1.92 & 1.69 & 1.49 & 1.21 \\
\hline $18: 2 n-6$ & 12.1 & 15.7 & 19.2 & 21.3 \\
\hline $18: 3 n-3$ & 1.58 & 8.94 & 16.3 & 23.2 \\
\hline $18: 4 n-3$ & 2.16 & 1.47 & 0.82 & 0.20 \\
\hline $20: 0$ & 0.30 & 0.30 & 0.31 & 0.29 \\
\hline $20: 1 n-9$ & 7.24 & 5.12 & 3.05 & 1.06 \\
\hline $20: 1 n-7$ & 0.21 & 0.16 & 0.09 & $\operatorname{tr}$ \\
\hline $20: 2 n-6$ & 0.17 & 0.12 & 0.11 & $\operatorname{tr}$ \\
\hline $20: 3 n-3$ & 0.08 & 0.07 & $\operatorname{tr}$ & $\operatorname{tr}$ \\
\hline $20: 4 n-6$ & 0.31 & 0.22 & 0.13 & $\operatorname{tr}$ \\
\hline $20: 4 n-3$ & 0.43 & 0.28 & 0.15 & $\operatorname{tr}$ \\
\hline $20: 5 n-3$ (EPA) & 6.86 & 4.68 & 2.75 & 0.94 \\
\hline $22: 0$ & $\operatorname{tr}$ & 0.16 & 0.16 & 0.17 \\
\hline $22: 1 n-11$ & 10.19 & 6.74 & 3.68 & 0.74 \\
\hline $22: 1 n-9$ & 0.56 & 0.43 & 0.29 & 0.16 \\
\hline $22: 2 n-6$ & 0.24 & 0.17 & $\operatorname{tr}$ & $\operatorname{tr}$ \\
\hline $22: 5 n-3$ & 0.64 & 0.40 & 0.18 & $\operatorname{tr}$ \\
\hline 22:6n-3 (DHA) & 8.34 & 5.68 & 3.38 & 1.06 \\
\hline Total & 96.9 & 97.7 & 98.9 & 98.4 \\
\hline Saturates & 25.3 & 24.5 & 22.9 & 21.7 \\
\hline Monoenes & 37.6 & 34.8 & 32.4 & 29.8 \\
\hline n-6 HUFA ${ }^{1}$ & 0.31 & 0.22 & 0.12 & 0.7 \\
\hline$n-3$ HUFA $^{1}$ & 16.3 & 11.9 & 6.5 & 2 \\
\hline
\end{tabular}

719 Fatty acids with more than 20 carbon atoms and more than 3 double bonds. 
720 Table 4. Primers for real-time PCR. Forward primer, f; reverse primer, r.

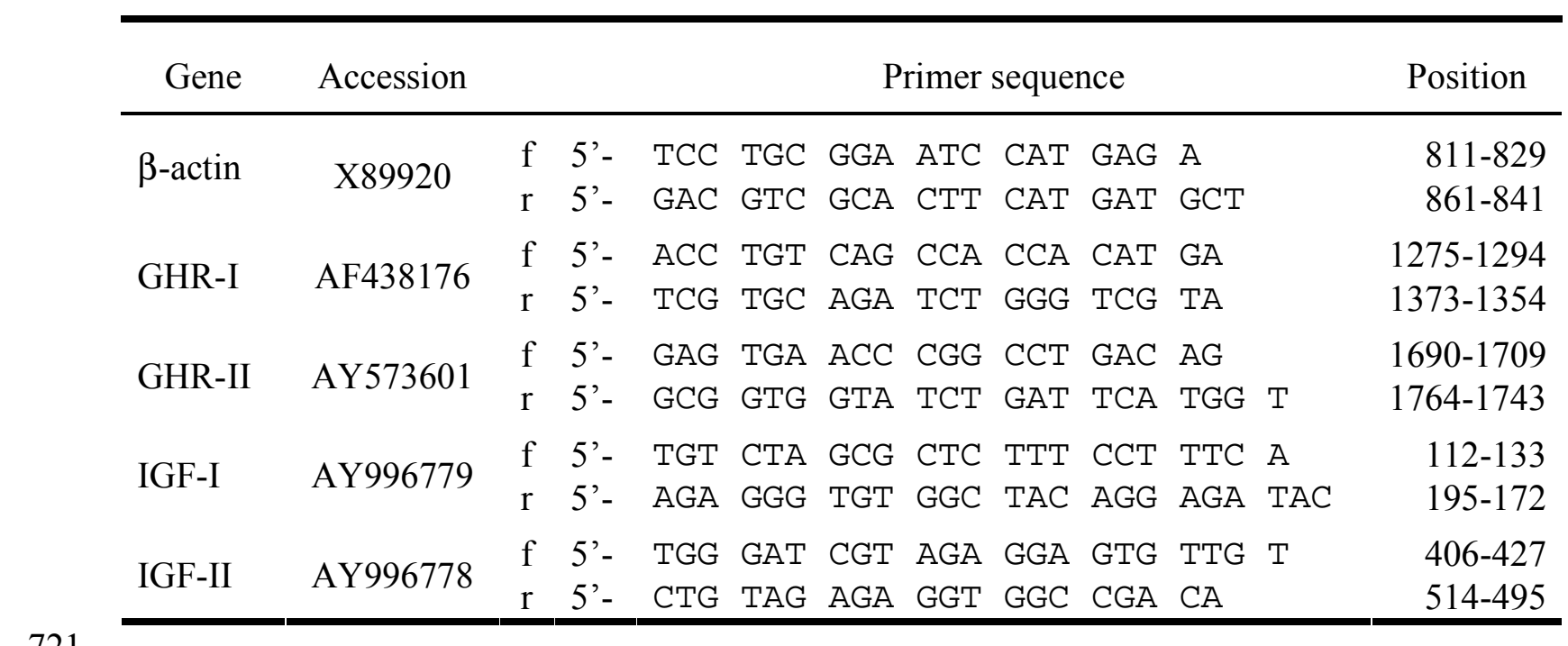


723 Table 5. Data on growth performance, whole body composition, and nutrient gain and retention of 724 gilthead sea bream fed the four experimental diets for 11 weeks. Each value is the mean \pm SEM of 725 data from triplicate groups. Data on viscera, liver and mesenteric fat indices were calculated from 72616 fish.

\begin{tabular}{|c|c|c|c|c|c|}
\hline & $\mathrm{FO}$ & $33 \mathrm{VO}$ & $66 \mathrm{VO}$ & $\mathrm{VO}$ & $P^{1}$ \\
\hline Initial body weight (g) & $16.1 \pm 0.09$ & $16.3 \pm 0.01$ & $16.3 \pm 0.03$ & $16.1 \pm 0.09$ & 0.31 \\
\hline Final body weight (g) & $91.7 \pm 0.45^{\mathrm{b}}$ & $91.3 \pm 0.90^{\mathrm{b}}$ & $91.1 \pm 1.20^{\mathrm{b}}$ & $80.9 \pm 0.28^{\mathrm{a}}$ & $<0.001$ \\
\hline Viscera $(\mathrm{g})$ & $8.28 \pm 0.45$ & $8.50 \pm 0.33$ & $8.37 \pm 0.31$ & $8.35 \pm 0.46$ & 0.77 \\
\hline Mesenteric fat $(\mathrm{g})$ & $1.72 \pm 0.24$ & $1.66 \pm 0.11$ & $1.79 \pm 0.15$ & $1.52 \pm 0.14$ & 0.43 \\
\hline Liver (g) & $1.78 \pm 0.12$ & $1.82 \pm 0.09$ & $1.92 \pm 0.08$ & $1.72 \pm 0.13$ & 0.68 \\
\hline VSI $(\%)^{2}$ & $9.36 \pm 0.30$ & $9.12 \pm 0.23$ & $9.10 \pm 0.24$ & $9.89 \pm 0.55$ & 0.28 \\
\hline MFI $(\%)^{3}$ & $1.78 \pm 0.23$ & $1.73 \pm 0.39$ & $1.95 \pm 0.17$ & $1.78 \pm 0.15$ & 0.45 \\
\hline $\operatorname{HSI}(\%)^{4}$ & $1.85 \pm 0.07$ & $1.93 \pm 0.11$ & $2.09 \pm 0.09$ & $2.02 \pm 0.16$ & 0.38 \\
\hline Liver fat (\%) & $15.9 \pm 0.83$ & $17.7 \pm 0.94$ & $18.7 \pm 1.05$ & $19.3 \pm 0.51$ & 0.06 \\
\hline DM intake (g/fish) & $68.8 \pm 0.60^{\mathrm{b}}$ & $68.9 \pm 0.66^{\mathrm{b}}$ & $67.6 \pm 0.25^{\mathrm{b}}$ & $61.3 \pm 0.77^{\mathrm{a}}$ & $<0.001$ \\
\hline Weight gain (\%) & $467.6 \pm 6.2^{\mathrm{b}}$ & $460.3 \pm 5.2^{\mathrm{b}}$ & $460.1 \pm 7.1^{\mathrm{b}}$ & $401.9 \pm 3.1^{\mathrm{a}}$ & $<0.001$ \\
\hline DGI $(\%)^{5}$ & $2.68 \pm 0.03^{\mathrm{b}}$ & $2.66 \pm 0.03^{b}$ & $2.66 \pm 0.05^{\mathrm{b}}$ & $2.43 \pm 0.02^{\mathrm{a}}$ & $<0.001$ \\
\hline $\mathrm{FE}^{6}$ & $1.10 \pm 0.01$ & $1.09 \pm 0.01$ & $1.11 \pm 0.02$ & $1.06 \pm 0.01$ & 0.07 \\
\hline PER $^{7}$ & $2.21 \pm 0.01$ & $2.23 \pm 0.01$ & $2.25 \pm 0.04$ & $2.14 \pm 0.02$ & 0.06 \\
\hline
\end{tabular}

Whole body composition (\% wet matter)

Moisture

Crude protein

Crude fat

$64.3+0.29$

$64.1 \pm 0.48$

$64.1 \pm 0.28$

$63.9 \pm 0.32$

0.70

$15.9 \pm 0.46$

$16.0 \pm 0.52$

$16.7 \pm 0.43$

$16.9 \pm 0.12$

0.10

$14.1 \pm 0.67$

$14.3 \pm 0.34$

$14.4 \pm 0.42$

$14.4 \pm 0.10$

0.95

Ash

$2.88 \pm 0.11$

$3.44 \pm 0.27$

$3.38 \pm 0.14$

$3.61 \pm 0.16$

0.09

Retention (\% intake)

Nitrogen

$35.4 \pm 1.27$

$35.1 \pm 1.12$

$36.9 \pm 1.92$

$37.3 \pm 0.63$

0.56

Energy

$50.1 \pm 2.01$

$50.3 \pm 1.06$

$52.5 \pm 0.55$

$51.9 \pm 0.76$

0.58

728 Initial body composition: water, $70.9 \%$; protein, $15.1 \%$; lipid, 9.3\%; ash, 3.4\%

$729{ }^{1} \mathrm{P}$ values result from analysis of variance. Different superscript letters in each row indicate significant

730 differences among dietary treatments (Student Newman-Keuls test, $\mathrm{P}<0.05$ ).

$731{ }^{2}$ Viscerosomatix index $=(100 \times$ viscera $w t) /$ fish wt

$732{ }^{3}$ Mesenteric fat index $=(100 \times$ mesenteric fat $w t) /$ fish wt

$733{ }^{4}$ Hepatosomatic index $=(100 \times$ liver wt $) /$ fish $w t$

$734{ }^{5}$ Daily growth index $=\left[100 \times\left(\right.\right.$ final fish $\mathrm{wt}^{1 / 3}-$ initial fish $\left.\left.\mathrm{wt}^{1 / 3}\right)\right] /$ days

$735{ }^{6}$ Feed efficiency $=$ wet weight gain / dry feed intake

$736{ }^{7}$ Protein efficiency ratio = wet weight gain / protein intake 
739 Figure 1. Plasma levels of insulin-like growth factor-I (IGF-I) in fish fed experimental diets $7405 \mathrm{~h}$ after the meal (A) and following overnight fasting (B). Each value is the mean $\pm \mathrm{SEM}$ 741 of 10 to 12 animals. Values with different letters are significantly different $(\mathrm{P}<0.05)$.

743 Figure 2. Plasma growth hormone (GH) levels in fish fed experimental diets $5 \mathrm{~h}$ after the 744 meal (A) and following overnight fasting (B). Each value is the mean \pm SEM of 10 to 12 745 animals.

Figure 3. Normalized mRNA levels of IGF-I (A) and IGF-II (B) in the liver of fish fed 748 experimental diets (20 h postfeeding). Each value is the mean \pm SEM of 6 to 8 animals. 749 Values with different letters are significantly different $(\mathrm{P}<0.05)$.

Figure 4. Normalized mRNA levels of GHR-I (A) and GHR-II (B) in the liver of fish fed 752 experimental diets ( $20 \mathrm{~h}$ postfeeding). Each value is the mean \pm SEM of 6 to 8 animals. 753 Values with different letters are significantly different $(\mathrm{P}<0.05)$.

755 Figure 5. Normalized mRNA levels of IGF-I (A) and IGF-II (B) in the skeletal muscle of 756 fish fed experimental diets (20 h postfeeding). Each value is the mean \pm SEM of 6 to 8 757 animals. Values with different letters are significantly different $(\mathrm{P}<0.05)$. 
759 Figure 6. Normalized mRNA levels of GHR-I (A) and GHR-II (B) in the skeletal muscle of

760 fish fed experimental diets $(20 \mathrm{~h}$ postfeeding). Each value is the mean \pm SEM of 6 to 8

761 animals. Values with different letters are significantly different $(\mathrm{P}<0.05)$.

762

763 Figure 7. Proposed model for the balanced regulation of systemic and local components of

$764 \mathrm{GH} / \mathrm{IGF}$ axis. Growth dysfunction occurs when the reduced production of systemic IGF-I is

765 not compensated at the local tissue level (fish fed VO diet). Compensatory IGF-II

766 production occurs at the local tissue level in fish fed FO diet. Alternatively, other

767 compensatory mechanisms of GH/IGF axis could be mediated at the local tissue level by

768 GHR-II via unknown factors, $\mathrm{X},(66 \mathrm{VO}$ diet). 
769 Figure 1

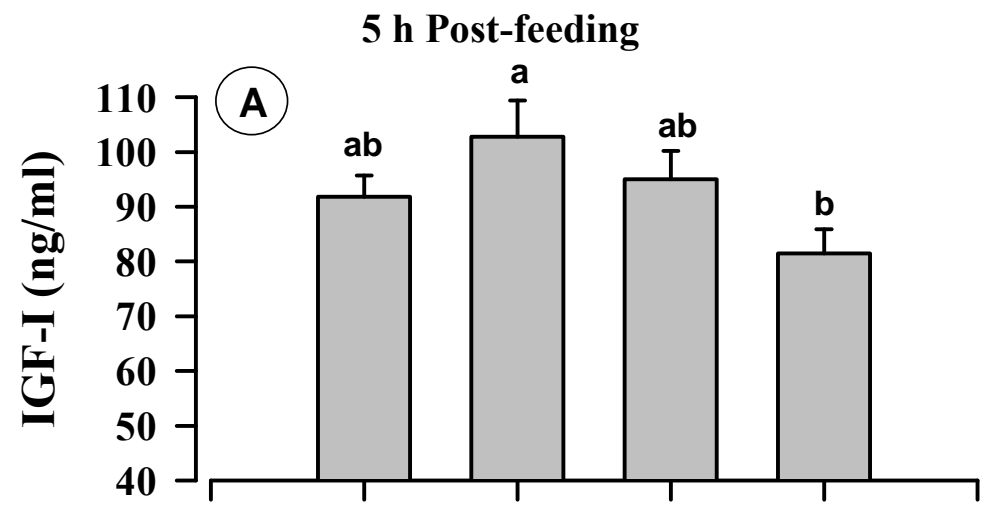

20 h Post-feeding

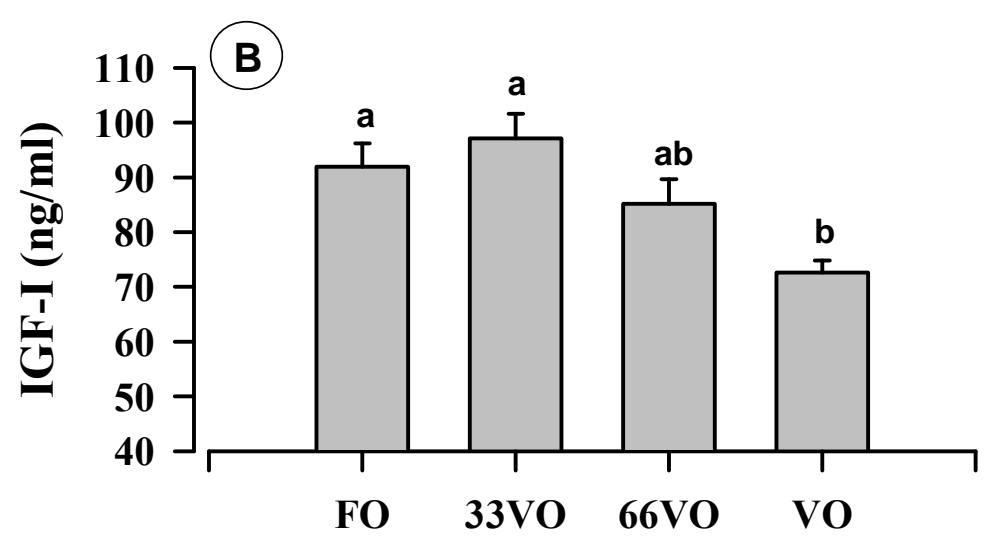


$771 \quad$ Figure 2

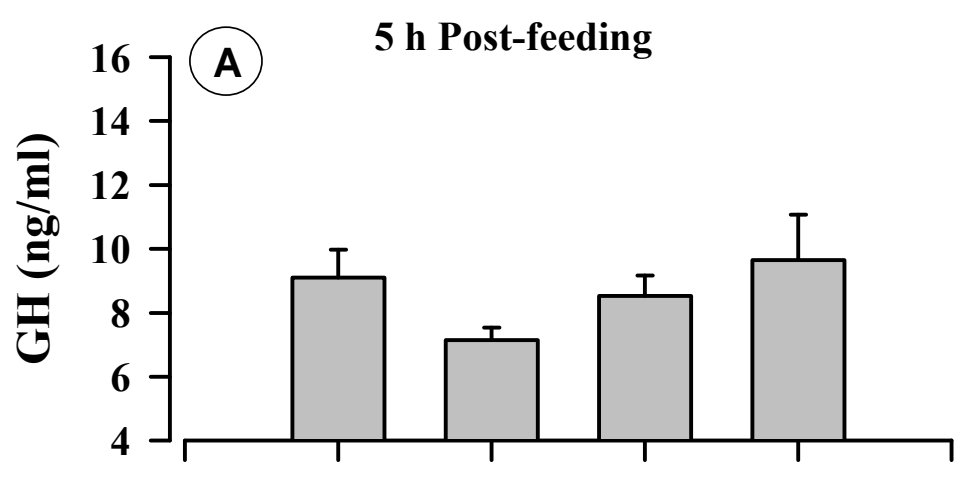

20 h Post-feeding

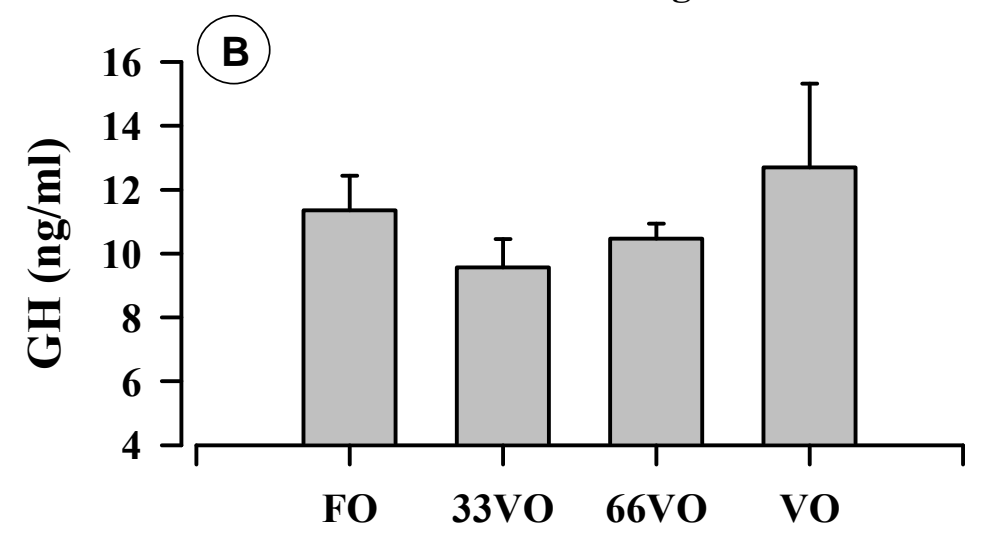


Figure 3
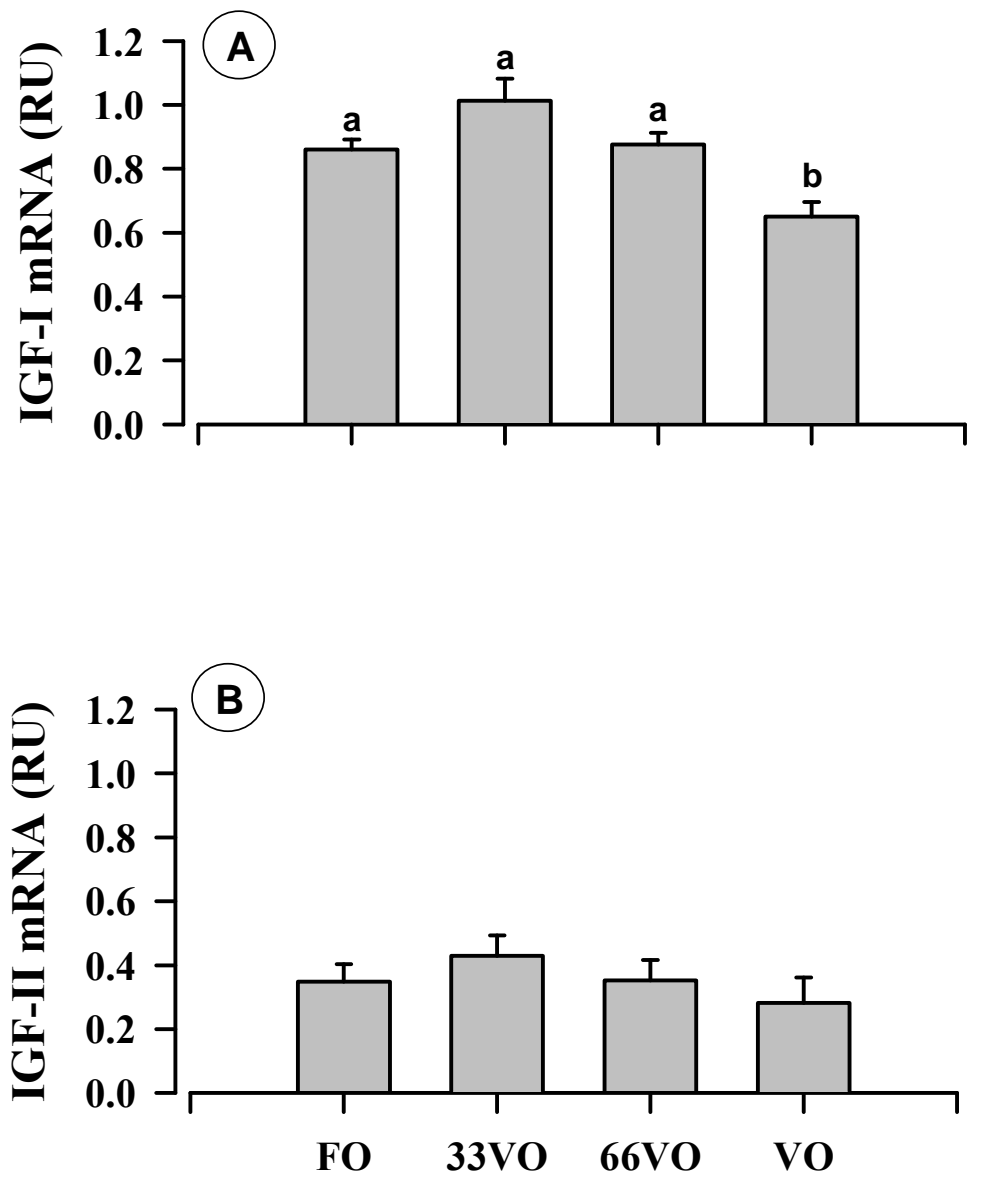
Figure 4
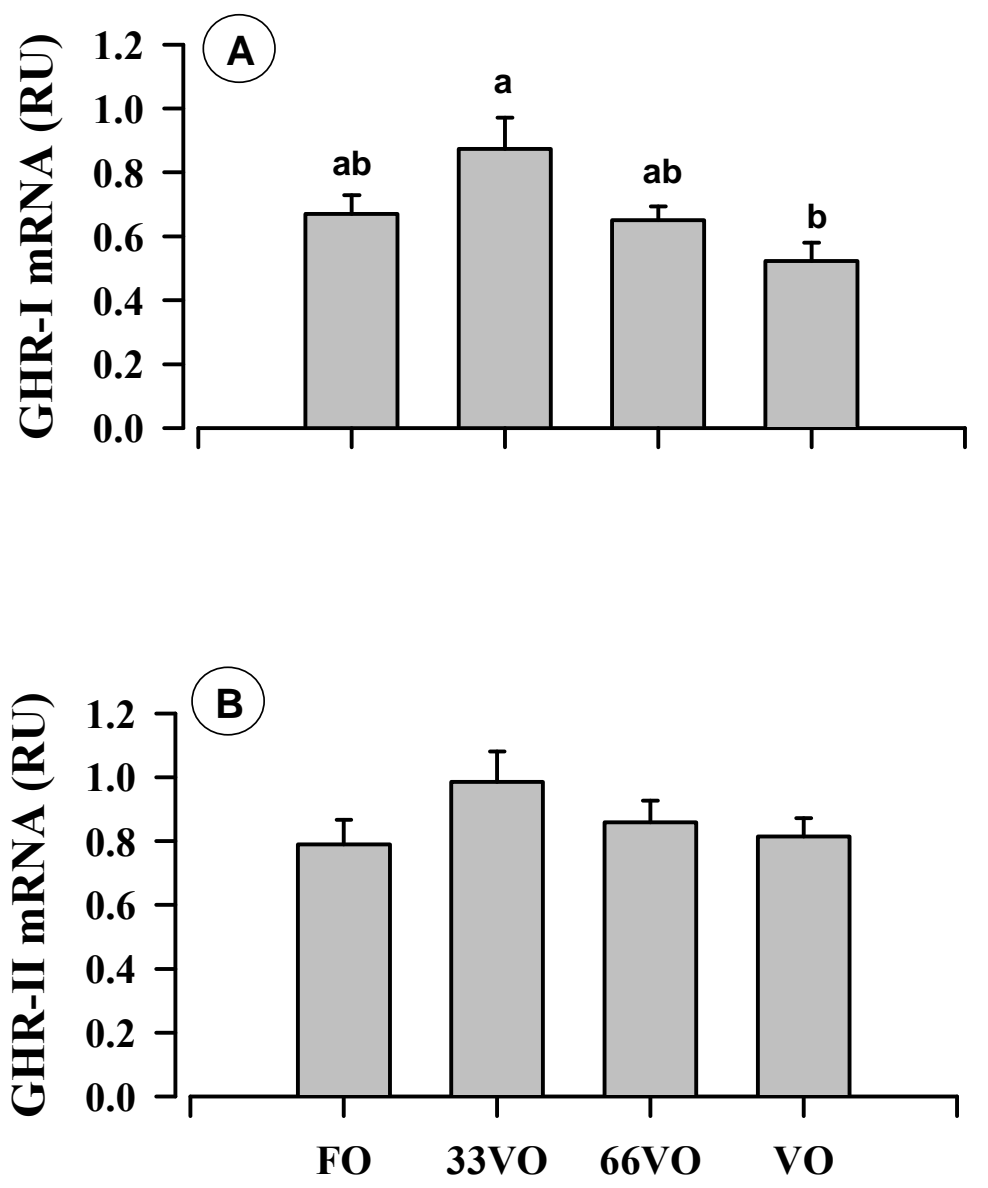
Figure 5
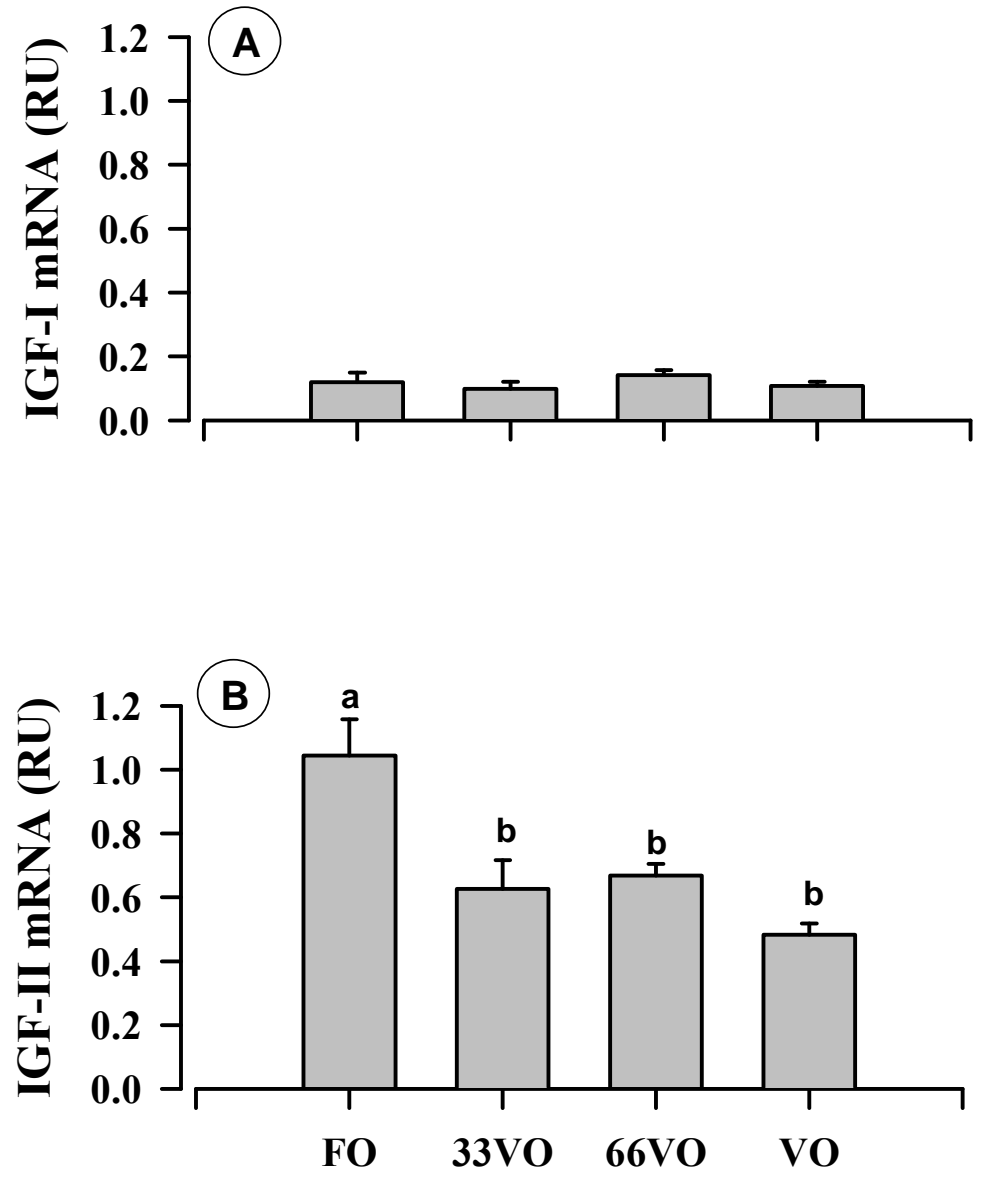
$779 \quad$ Figure 6
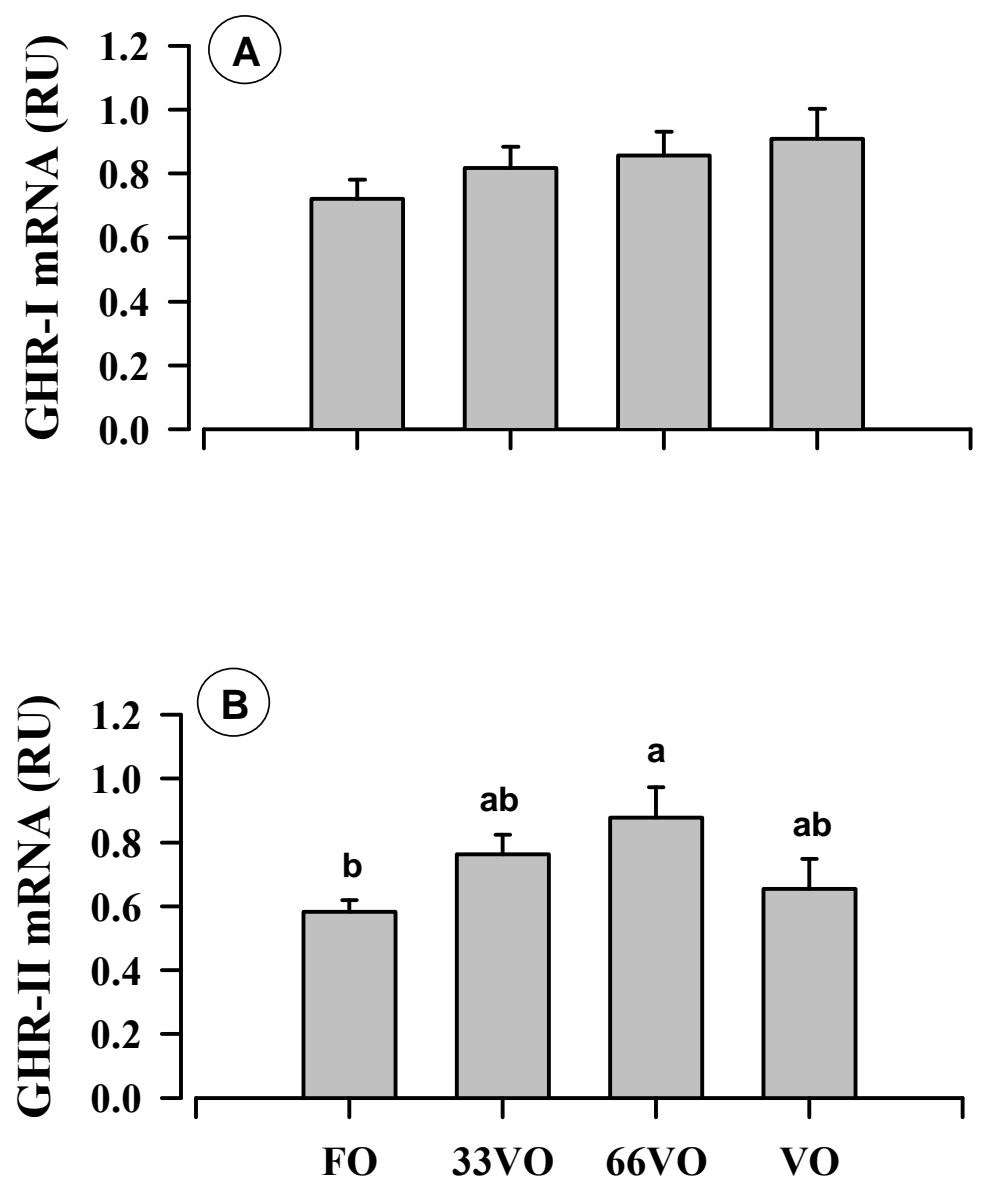
$781 \quad$ Figure 7

782
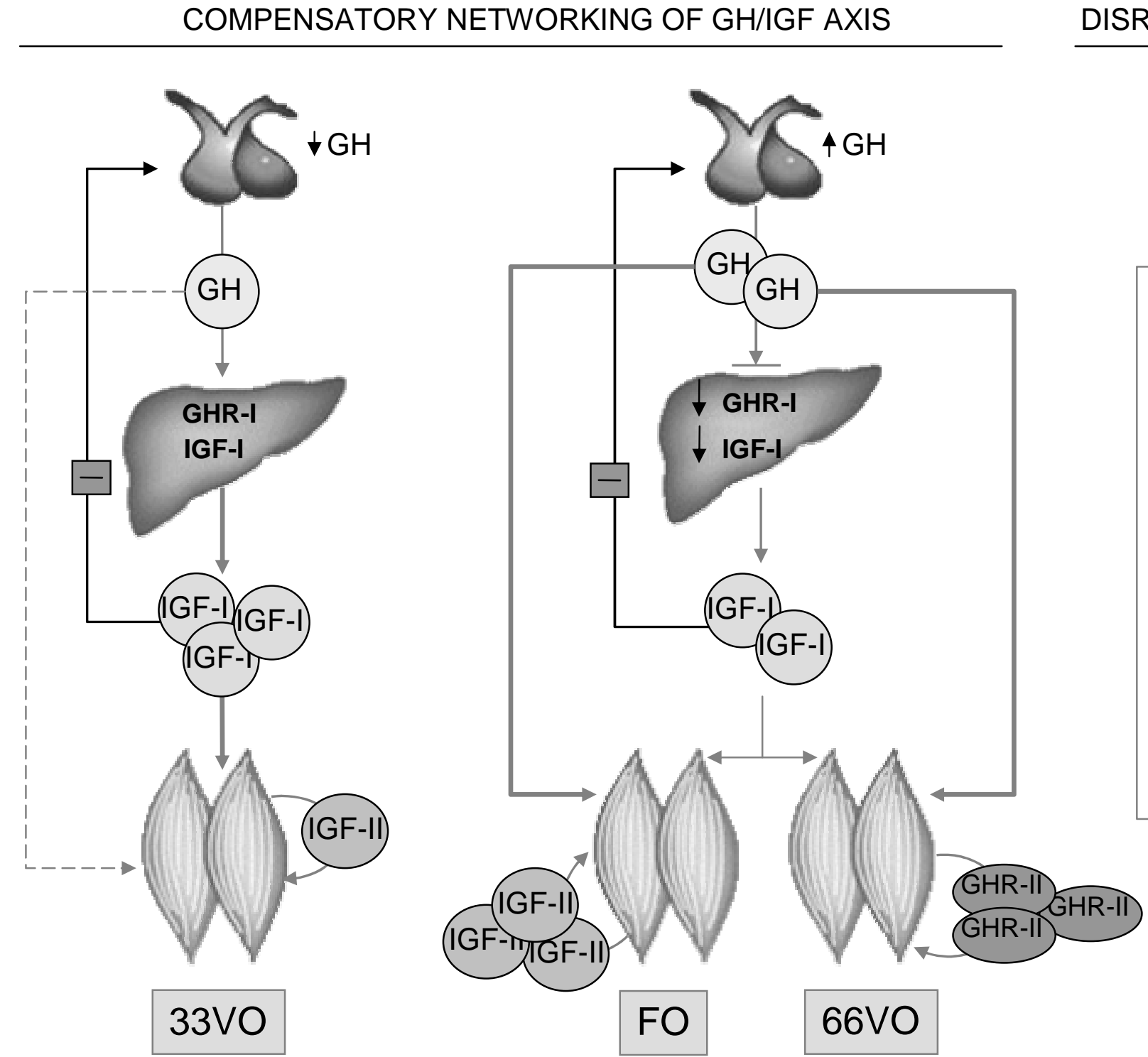

DISRUPTION OF GH/IGF AXIS

783

33VO

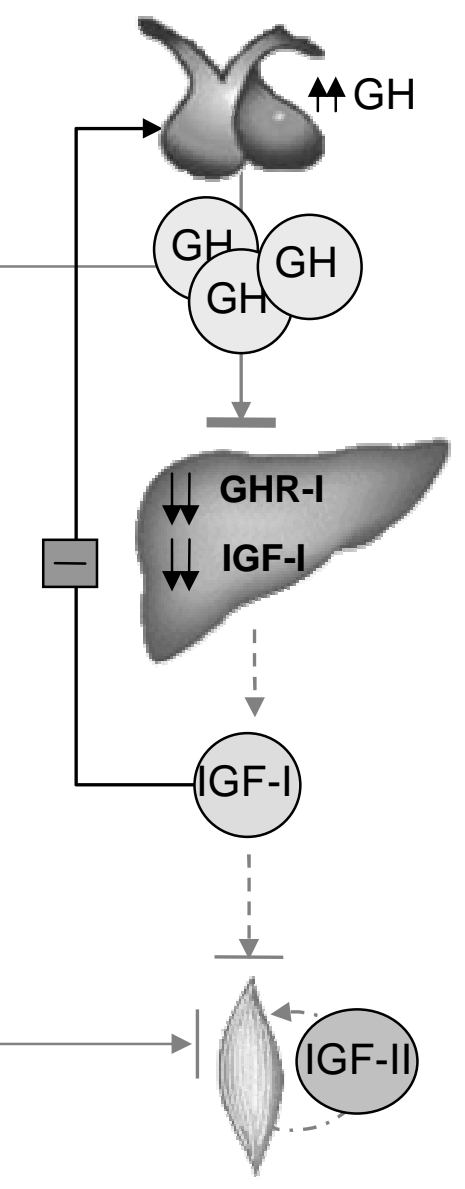

VO 
